\title{
Anti-Myeloma Monoclonal Antibody-DM4 Immunoconjugate BT-062
}

National Cancer Institute

\section{Source}

National Cancer Institute. Anti-Myeloma Monoclonal Antibody-DM4 Immunoconjugate

BT-062. NCl Thesaurus. Code C78840.

An immunoconjugate consisting of a monoclonal antibody directed against a highlyexpressed myeloma cell surface antigen covalently attached to the maytansinoid DM4, a derivative of the cytotoxic agent maytansine (DM1), with potential antineoplastic activity. Anti-myeloma cell surface antigen immunoconjug ate BT-062 binds to an unspecified cell surface antigen highly expressed on myeloma cells; upon internalization the DM4 moiety is released, binding to tubulin and disrupting microtubule assembly/disassembly dynamics, which may result in the inhibition of cell division and cell growth of myeloma tumor cells. 